\title{
Productivity-Diversity Relationships from Chemolithoautotrophically Based Sulfidic Karst Systems
}

\author{
Megan L. Porter ${ }^{1 *}$, Annette Summers Engel ${ }^{2 *}$, Thomas C. Kane ${ }^{3 \dagger}$, Brian K. Kinkle
}

\begin{abstract}
:
Porter M.L., Summers Engel A., Kane T.C. and Kinkle B.K. 2009. Productivity-Diversity Relationships from Chemolithoautotrophically Based Sulfidic Karst Systems. International Journal of Speleology, 38 (1), 27-40. Bologna (Italy). ISSN $0392-6672$.

Although ecosystems thriving in the absence of photosynthetic processes are no longer considered unique phenomena, we have yet to understand how these ecosystems are energetically sustained via chemosynthesis. Ecosystem energetics were measured in microbial mats from active sulfidic caves (Movile Cave, Romania; Frasassi Caves, Italy; Lower Kane Cave, Wyoming, USA; and Cesspool Cave, Virginia, USA) using radiotracer techniques. We also estimated bacterial diversity using 16S rRNA sequences to relate the productivity measurements to the composition of the microbial communities. All of the microbial communities investigated were dominated by chemolithoautotrophic productivity, with the highest rates from Movile Cave at $281 \mathrm{~g} \mathrm{C} / \mathrm{m}^{2} / \mathrm{yr}$. Heterotrophic productivities were at least one order of magnitude less than autotrophy from all of the caves. We generated 414 new $16 \mathrm{~S}$ rRNA gene sequences that represented 173 operational taxonomic units (OTUs) with $99 \%$ sequence similarity. Although $13 \%$ of these

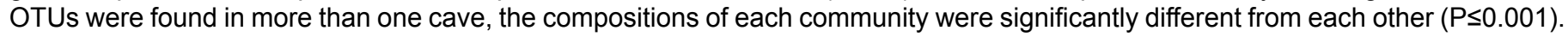
Autotrophic productivity was positively correlated with overall species richness and with the number of bacterial OTUs affiliated with the Epsilonproteobacteria, a group known for sulfur cycling and chemolithoautotrophy. Higher rates of autotrophy were also strongly positively correlated to available metabolic energy sources, and specifically to dissolved sulfide concentrations. The relationship of autotrophic productivity and heterotrophic cycling rates to bacterial species richness can significantly impact the diversity of higher trophic levels in chemolithoautotrophically-based cave ecosystems, with the systems possessing the highest productivity supporting abundant and diverse macro-invertebrate communities.
\end{abstract}

Keywords: karst, ecosystem, chemolithoautotrophy, productivity, diversity

Received 5 May 2008; Revised 2 September 2008; Accepted 17 September 2008

\section{INTRODUCTION}

Microorganisms in most natural systems have typically been considered ecologically important in the cycling of carbon through the 'microbial loop' and decomposer niches (e.g., Azam et al., 1993; Bachofen et al., 1998). The discovery of diverse communities at deep-sea hydrothermal vents and cold seeps brought to light the importance of microorganisms as significant contributors to ecosystem autotrophic processes (e.g., Deming \& Baross, 1993; Sassen et al., 1993). Indeed, chemolithoautotrophy (e.g., metabolic pathways where energy is gained from inorganic compounds

1 Department of Biological Sciences, University of Maryland at Baltimore County, Baltimore, Maryland USA 21250; porter@ umbc.edu

2 Department of Geology \& Geophysics, Louisiana State University, Baton Rouge, Louisiana USA 70803; aengel@geol. 1su.edu

3 Department of Biological Sciences, University of Cincinnati, Cincinnati, Ohio USA 45221; brian.kinkle@uc.edu

* Equal contributions

$\dagger$ Deceased and carbon from $\mathrm{CO}_{2}$ ) and chemosynthetically-based ecosystems are no longer considered unique (e.g., Stevens \& McKinley, 1995; Stevens, 1997; Bachofen et al., 1998; Kinkle \& Kane, 2000; Pedersen, 2001; Chapelle et al., 2002; Barton et al., 2007). Yet, how these microbial communities function in situ is still poorly understood and few detailed ecosystem analyses have been attempted. One reason for this is the fact that most chemolithoautotrophically-based ecosystems are in environments that are physically difficult to study (i.e. deep-sea and deep-aquifer).

There have been relatively few studies delineating energy flow in cave and karst systems (e.g., Brown et al., 1994; Simon et al., 2001; Simon \& Benfield, 2002; Simon et al., 2007), and even fewer investigations of ecosystem energetics from solely chemolithoautotrophically-based cave and karst ecosystems (e.g., Mattison et al., 1998; Porter, 1999). Most of the ecosystem studies from chemolithoautotrophic karst systems have been done using stable isotope ratio systematics for the purpose of delineating trophic relationships within the food web (e.g., Sarbu et al., 1996; Sarbu et al., 2000; 
Vlasceanu et al., 2000; Engel, 2007). But, this work treated the microbial communities and the primary producers as "black boxes", rarely describing the diversity of the microbial communities, determining the relative rates of microbial autotrophic versus heterotrophic productivity, or linking community diversity to microbial productivity (e.g., the rate of conversion of resources to biomass per unit area per unit time; Waide et al., 1999).

The relationships between ecosystem primary productivity and species diversity are complex (Waide et al., 1999), exhibiting six possible patterns, including random (i.e. no pattern), flat, positive, negative, U-shaped, and hump-shaped (e.g., Smith, 2007). There has been much debate about the mechanisms resulting in these patterns (e.g., McCann, 2000; Fukami \& Morin, 2003), based on the fact that similar systems can respond differently when affected by disturbance, consumer dynamics, niche specialization, the temporal history of the community assembly, ecological parameters, or spatial scales within and among communities, and community structure and composition over time, (e.g., Abrams, 1995; Naeem \& Li, 1998; Chesson et al., 2002; Naeem, 2002; Torsvik et al., 2002; Fukami \& Morin, 2003; Horner-Devine et al., 2003; Smith, 2007). However, in all of this, there have been few studies that evaluated productivity-diversity relationships for microbial systems, and fewer still in bacterial communities. Here we present research investigating the productivity-diversity relationships of bacterial communities found in chemolithoautotrophic karst ecosystems, as representatives of some of the most productive cave communities yet documented (Sarbu et al., 1996; Sarbu et al., 2000; Engel, 2007).

To investigate productivity-diversity relationships, we first assessed the autotrophic and heterotrophic productivity in these chemolithoautotrophic subterranean microbial communities. Three different radioactive tracers were used to estimate the production in different components of the microbial samples: $\left[{ }^{14} \mathrm{C}\right]$-bicarbonate, $\left[{ }^{14} \mathrm{C}\right]$-leucine, and $\left[{ }^{14} \mathrm{C}\right]-$ acetate. $\left[{ }^{14} \mathrm{C}\right]$-bicarbonate measures the rates of autotrophy in both eukaryotic and prokaryotic systems (e.g., Wetzel \& Likens, 1991; Pederson \& Ekendahl, 1992). Assessing the rates of heterotrophic activity is also crucial to understanding the energetics of the system, and specifically how much carbon could be cycled through a 'microbial loop' before being utilized by higher trophic levels (e.g., Pimm, 1988; Lampert \& Sømmer, 1997; Chesson et al., 2002; Naeem, 2002). $\left[{ }^{14} \mathrm{C}\right]$-leucine incorporations are a common technique in aquatic studies of heterotrophic microbial productivity because leucine is incorporated almost exclusively into proteins (e.g., Kirchman et al., 1985; Jørgensen, 1992; Kirchman, 1993; Touminen, 1995; Díaz-Raviña \& Bååth, 1996). $\left[{ }^{14} \mathrm{C}\right]$-acetate is a sensitive tracer (e.g., Findlay et al., 1985; Phelps et al., 1989; Phelps et al., 1994) that is incorporated solely by bacteria over short incubation times (Munro \& Brock, 1968). It is used as a second estimate of heterotrophy and chemoorganotrophy (e.g., metabolic process that derives energy from inorganic compounds and carbon from organic molecules), and can indicate the activity of a variety of microbes, such as sulfate-reducing bacteria, as well as acetotrophic methanogens (e.g., Kelly, 1967; Wallace et al., 1970; Weber et al., 1984; Schauder et al., 1986).

A second goal was to provide a comparative assessment of the bacterial 16S rRNA gene sequence diversity to evaluate possible productivitydiversity relationships (e.g., Kaunzinger \& Morin, 1998; McCann, 2000; Torsvik et al., 2002; Smith, 2007). Ecological concepts pertaining to plants and animals are just beginning to be applied to microbial ecosystems (e.g., Kaunzinger \& Morin, 1998; Chesson et al., 2002; Naeem, 2002; Horner-Devine et al., 2003; Smith, 2007), and we evaluate the implications of our productivity-diversity in an ecosystem framework. These results are the first to link primary productivity and heterotrophic cycling rates to bacterial diversity in terrestrial, subsurface, chemolithoautotrophic systems.

\section{Site Descriptions \\ Lower Kane Cave, Wyoming, USA}

Lower Kane Cave is located in north-central Wyoming (Figure 1). Four sulfidic springs discharge into the cave passage, and thick white filamentous mats occur within the spring orifices and downstream of the springs. The cave and the microbial communities have been extensively described (e.g., Engel et al., 2004); we focused our analysis on the white
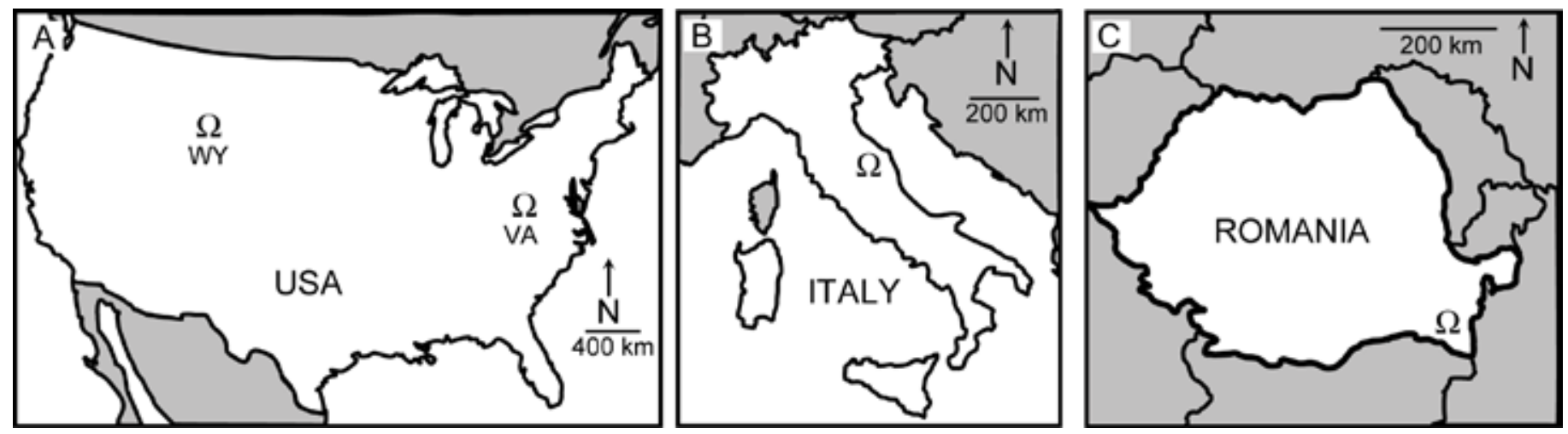

Fig. 1. Locations maps for four caves, (A) Lower Kane Cave, Wyoming, and Cesspool Cave, Virginia; (B) the Frasassi Caves, Italy, and (C) Movile Cave, Romania. 
filamentous microbial mats from the Lower Spring. Large populations of the stygobitic snail, Physella spelunca, are supported by the microbial productivity in this system (Porter et al., 2002).

\section{Cesspool Cave, Virginia, USA}

Cesspool Cave is a small opening developed in a travertine-marl complex of Quaternary age located along the Sweet Springs Creek (Figure 1) (Hubbard et al., 1990; Engel et al., 2001). A sulfidic spring discharges into a back pool, flows out of the cave, and resurges into a surface pond. White filamentous microbial mats occur in the resurgent spring and in the dark zone. Engel et al. (2001) described the bacterial diversity from Cesspool Cave based on clone groups from restriction fragment length polymorphism (RFLP) efforts, revealing the presence of two different groups within the Epsilonproteobacteria, Thiothrix spp., and Bacteroidetes [GenBank accession numbers AF207530- AF207534] (Engel et al., 2001). We focus on the dark zone mats for this study. There are no known cave-adapted macro-fauna using the chemolithoautotrophically fixed carbon in Cesspool Cave (Engel et al., 2001).

\section{Frasassi Caves, Italy}

The Frasassi Caves in Central Italy (Figure 1) are comprised of multiple caves, including Grotta Grande del Vento, Grotta del Fiume, and Grotta Sulfurea (Galdenzi \& Menichetti, 1995). Thick white filamentous mats cover the surface of the substrate in sulfidic cave streams. Microbial mats from a stream passage in the Grotta del Fiume were used for the incorporation studies, and microbial mats from the downstream section of the Grotta Sulfurea for 16S rRNA gene sequence diversity; these sites are separated by $<150 \mathrm{~m}$ of stream flow. Twelve terrestrial (5 endemic troglobites) and three aquatic ( 2 endemic stygobites) animals have been described from the sulfidic stream sections of the Frasassi Caves (Sarbu et al., 2000; Engel, 2007). The microbial communities from the Frasassi Caves have been the foci of recent phylogenetic and geomicrobiological research, confirming the high microbial diversity (Sarbu et al., 2000; Vlasceanu et al., 2000; Macalady et al., 2006; Macalady et al., 2008) and complex sulfur cycling (Engel et al., 2007) of this ecosystem

\section{Movile Cave, Romania}

Since the cave was discovered in southeastern Romania in 1986 (Figure 1), studies have revealed that Movile Cave is an access point to a large sulfidic aquifer that contains 33 new cave-adapted taxa identified from 30 terrestrial species (24 endemic troglobites) and 18 aquatic species (9 endemic stygobites) (Sarbu et al., 1996). These high numbers make Movile Cave a subterranean biodiversity hotspot (Culver \& Sket, 2000). Because there are no natural entrances, the cave is energetically isolated from the surface. The 0.3-3 mm thick microbial mats float on the water in air pockets of the submerged passages. The atmosphere in the air bells contains $7-10 \% \mathrm{O}_{2}, 2-3.5 \% \mathrm{CO}_{2}, 1-2 \%$
$\mathrm{CH}_{4}$, with trace $\mathrm{H}_{2} \mathrm{~S}$, and only a few millimeters of the cave water below the mats are oxygenated (Sarbu et al., 1996; Popa, 1997; Badescu, 1998). Although the microbial communities from Movile Cave have been of interest for more than a decade (e.g., Sarbu et al., 1996; Vlasceanu et al., 1997; Rohwerder et al., 2003) and various metabolic guilds have been investigated (Hutchens et al., 2004), there has not been a concerted effort to describe the overall microbial diversity of the mats using a 16S rRNA framework. To our knowledge, we report here the first 16S rRNA gene sequence diversity data for bacteria for the floating microbial mats from Movile Cave.

\section{Sample Collection and Physicochemical Analyses}

Physicochemical measurements were made in the caves using previously described methods (Engel et al., 2004). Water from each of the caves was fixed with zinc acetate and sodium hydroxide and taken back to the lab for analysis of sulfide concentration using a modified methylene blue method. Separate water samples were collected at each site, kept on ice, and transported back to the lab where alkalinity was measured by titration with $0.2 \mathrm{~N}$ sulfuric acid. Samples from the cave microbial mats were acquired from 1998 through 2003. The incorporation studies were done in 1998 for Movile Cave and the Frasassi Caves, and in 1999 for Lower Kane Cave and Cesspool Cave. Approximately $0.5-1 \mathrm{ml}$ of biological material was preserved in $50 \%$ glycerol, snap-frozen in liquid $\mathrm{N}_{2}$, and archived at $-80^{\circ} \mathrm{C}$.

\section{Radiolabeled Substrate Incubations and Productivity Analysis}

Parallel experiments were run with all radioisotopes. Experiments and incubations were cautiously done in the caves in designated areas away from the microbial mats or cave streams, and all incubations were done in secondary containment boxes. Aliquots of homogenized biomass material were transferred to $20 \mathrm{ml}$ plastic scintillation vials containing $10 \mathrm{ml}$ of $0.22 \mu \mathrm{m}$ filter-sterilized water from each site. Each mat aliquot received either $0.2-1 \mu \mathrm{Ci}$ of $\left[{ }^{14} \mathrm{C}\right]$-sodium bicarbonate $(56 \mathrm{mCi} / \mathrm{mmol}), 0.2 \mu \mathrm{Ci}$ of $\left[\mathrm{U}-{ }^{14} \mathrm{C}\right]-$ leucine $(320 \mathrm{mCi} / \mathrm{mmol})$, or $\left[1,2-{ }^{14} \mathrm{C}\right]$-acetic acid $(116$ $\mathrm{mCi} / \mathrm{mmol}$ ). The high concentrations of leucine $(67$ $\mathrm{nmol} / \mathrm{L})$ were used to minimize intracellular dilution (Jørgensen, 1992). All radiolabels were purchased from ICN Pharmaceuticals (Costa Mesa, California, USA). Replicate samples for each radiolabel were incubated in sealed vials (two replicates for the Frasassi, Lower Kane, and Cesspool Caves, and three for Movile Cave). Incubations were stopped with the addition of formalin (final concentration of $4 \%$ ) or thimerosal (final concentration of $0.01 \%$ ). Incubations with fixative added before the radiolabels were used as negative controls. For each location a time series was run to determine the optimal incubation times, with replicate samples fixed after the incubation times of 15,30 , and $60 \mathrm{~min}$. Incorporation rates decreased over the course of the time series, and so a $15 \mathrm{~min}$ incubation time was used as our estimate of maximum 
incorporation rates.

Fixed samples of each radiolabel were taken from the caves to the lab to measure biomass and total incorporated radioactivity. A subsample from each replicate was filtered using $0.2-\mu \mathrm{m}$ nitrocellulose filters and washed with water. $\left[{ }^{14} \mathrm{C}\right]$-bicarbonate incubations were also washed with $0.1 \mathrm{M} \mathrm{HCl}$ and leucine samples with cold trichloroacetic acid to remove any excess radiolabel. Filtered samples were dried, weighed, dissolved using NCS tissue solubilizer, suspended in scintillation fluid, and counted on a Packard 2200ca Tri-carb scintillation counter. Rates of productivity for each radiolabel were determined from the total counts incorporated minus the negative control activity and standardized using the milligrams dry weight (mgdw) of each sample. Rates of primary productivity in terms of ${ }^{12} \mathrm{C}$ were calculated using the methods of Wetzel and Likens (1991), while heterotrophic biomass production was estimated using a conversion factor of $3.1 \mathrm{mg} \mathrm{C} /$ mol $\left[{ }^{14} \mathrm{C}\right]$-leucine incorporated (Kirchman, 1993).

\section{Bacterial 16S rRNA Gene Diversity Clone Library Construction}

DNA extraction from archived material from the Movile, Frasassi, and Cesspool Caves was done in 2004 and 2007. Biological material was thawed on ice, and total environmental nucleic acids were extracted directly in the thawed sample tube after adding sterile cell lysis buffer $(10 \mathrm{mM}$ Tris and 100mM EDTA, pH 8.0). Extraction methods were previously described (Engel et al., 2003; Engel et al., 2004). DNA purity and concentration for each extraction were determined spectrophotometrically using standard OD 260/280 absorbance methods on a NanoDrop ND-1000 UV/Vis spectrophotometer (NanoDrop Technologies, USA).

16S rRNA gene sequences were obtained by PCR amplification using the eubacterial primer pair $8 \mathrm{f}$ (forward, 5'-AGAGTTTGATCCTGGCTCAG-3') and 1510r (reverse, 5'-GGTTACCTTGTTACGACTT-3'). Amplification was performed with a MJ Research thermal cycler with $5 \mathrm{U} / \mu \mathrm{l}$ Hotmaster Taq DNA polymerase (Eppendorf, USA). Optimal PCR products were obtained using the following cycle profile: an initial hot start at $94^{\circ} \mathrm{C}$ for $4 \mathrm{~min}$, followed by denaturation at $94^{\circ} \mathrm{C}$ for $1 \mathrm{~min}$, primer annealing at $41^{\circ} \mathrm{C}$ for $1 \mathrm{~min}$, chain extension at $72^{\circ} \mathrm{C}$ for 1 min, repeated for 29 more cycles, followed by a final extension step for $20 \mathrm{~min}$ at $72^{\circ} \mathrm{C}$. Amplified bacterial PCR products were purified by using a $0.7 \%$ TAE low-melt agarose gel with a Millipore Montage purification system (Millipore). Purified products were cloned using the TOPO Cloning Kit, according to manufacturer instructions (Invitrogen Corp., USA). Clones were screened by PCR with the M13-Forward (5'-GTAAAACGACGGCCAG-3') and M13-Reverse (5'-CAGGAAACAGCTATGAC-3') primers (Invitrogen Corp., USA). Over 100 clones were screened for each library (Cesspool Cave, 125 clones; Frasassi Caves, 124 clones; Movile Cave, 165 clones). For our phylogenetic and comparative analyses here, we used the Lower Spring sequences for Lower Kane Cave that were generated from RFLP analyses of 167 clones [GenBank accession numbers AY510185AY510186, AY510202, AY510205, AY510211, AY510246-AY510251, AY510261-AY510262] (Engel et al., 2004).

\section{Sequencing and Phylogenetic Analyses}

Amplified inserts were sequenced using a capillary autosequencer (e.g., ABI Prism 3730) with an ABI bigdye Ready-Reaction kit. Resulting clone sequences were assembled using ContigExpress, a component of Vector NTI Advance 10.3.0 (Invitrogen Corp., USA). An initial alignment of all clone sequences and closely related environmental and isolate sequences, as well as screening for chimera, was done with the greengenes alignment tool (DeSantis et al., 2006a; DeSantis et al., 2006b) (http://greengenes.lbl.gov/). The resulting alignment was further refined using MAFFT (Katoh et al., 2002; Katoh et al., 2005), and poorly aligned and divergent regions were removed using Gblocks v.0.91b (http://www.phylogeny.fr/ phylo_cgi/gblocks.cgi) (Castresana, 2000; Talavera \& Castresana, 2007).

Operational taxonomic units (OTUs) were calculated to compare community composition and diversity among sites. A distance matrix was constructed with the PHYLIP v3.6 DNADIST module under the most complex model available, the F84 model of evolution (Felsenstein, 1989). Designation of OTUs representing the $\sim 99 \%$ sequence similarity predicted for specieslevel relationships using 16S rRNA gene sequences (e.g., Stackebrandt \& Goebel, 1994; Gevers et al., 2005) was done in DOTUR using the furthest-neighbor clustering algorithm (http://www.plantpath.wisc. edu/fac/joh/dotur.html) (Schloss \& Handelsman, 2005).

Rarefaction curves were generated using aRarefactWin (version 1.3; S. Holland; http://www.uga.edu/ strata/ software/) (Figure 2). Richness and diversity indices were computed using EstimateS (version 7.5, R. K. Colwell, http://purl.oclc.org/estimates). Because the clone data for Lower Kane Cave were acquired from restriction fragment length polymorphism (RFLP) analyses (Engel et al., 2004), these coverage and richness estimators

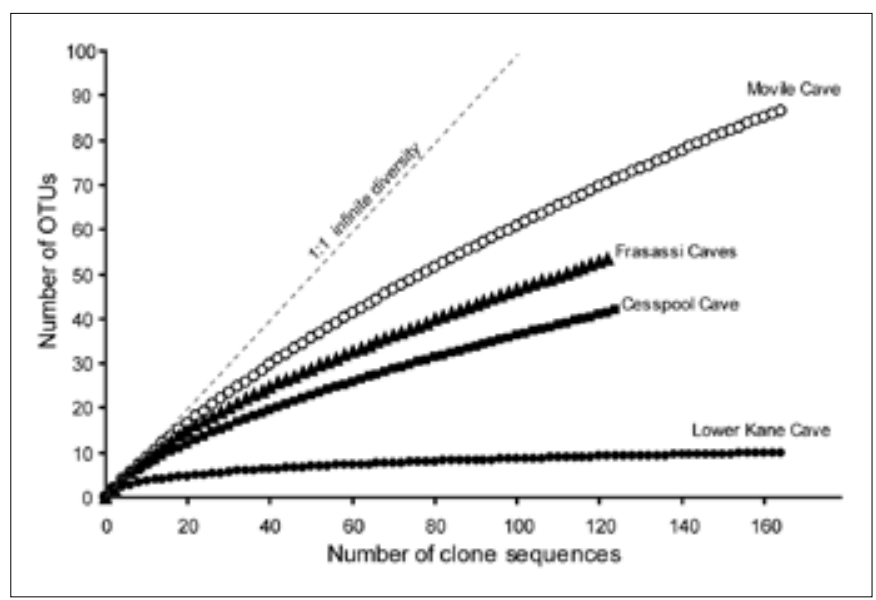

Fig. 2. Rarefaction curves for $16 \mathrm{~S}$ rRNA sequence richness within clone libraries derived from cave microbial mats. OTUs were defined as groups sharing $99 \%$ sequence identities. The Lower Kane Cave clone library and OTUs were defined from RFLP patterns. 
were not directly comparable to those resulting from sequencing efforts for the other three caves and were therefore not calculated. The similarities between the 16S rRNA clone libraries were evaluated using webLIBSHUFF (version 0.96) (J.R. Henriksen, 2004; http://libshuff.mib.uga.edu/), the web interface of the LIBSHUFF program (version 1.22) (Singleton et al., 2001; Singleton et al., in press). The distance matrix constructed with the PHYLIP v3.6 DNADIST module for DOTUR was used as the input file.

A phylogenetic tree of one representative sequence from each site for each OTU, including sequences of the most closely related isolates for the major OTU groups, was reconstructed with the neighbor joining algorithm in PAUP* v4b10 (Swofford, 2002) using the same model of evolution as the DOTUR analysis (F84). Sequences from the Deinococcus-Thermus phyla were used as outgroups to root the tree (Fig. 4).

\section{Nucleotide Sequence Accession Numbers}

The 16S rRNA gene sequences obtained in this study for the Cesspool Cave, Movile Cave, and Frasassi Cave have been deposited in the GenBank database under the accession numbers EU662292- EU662664.

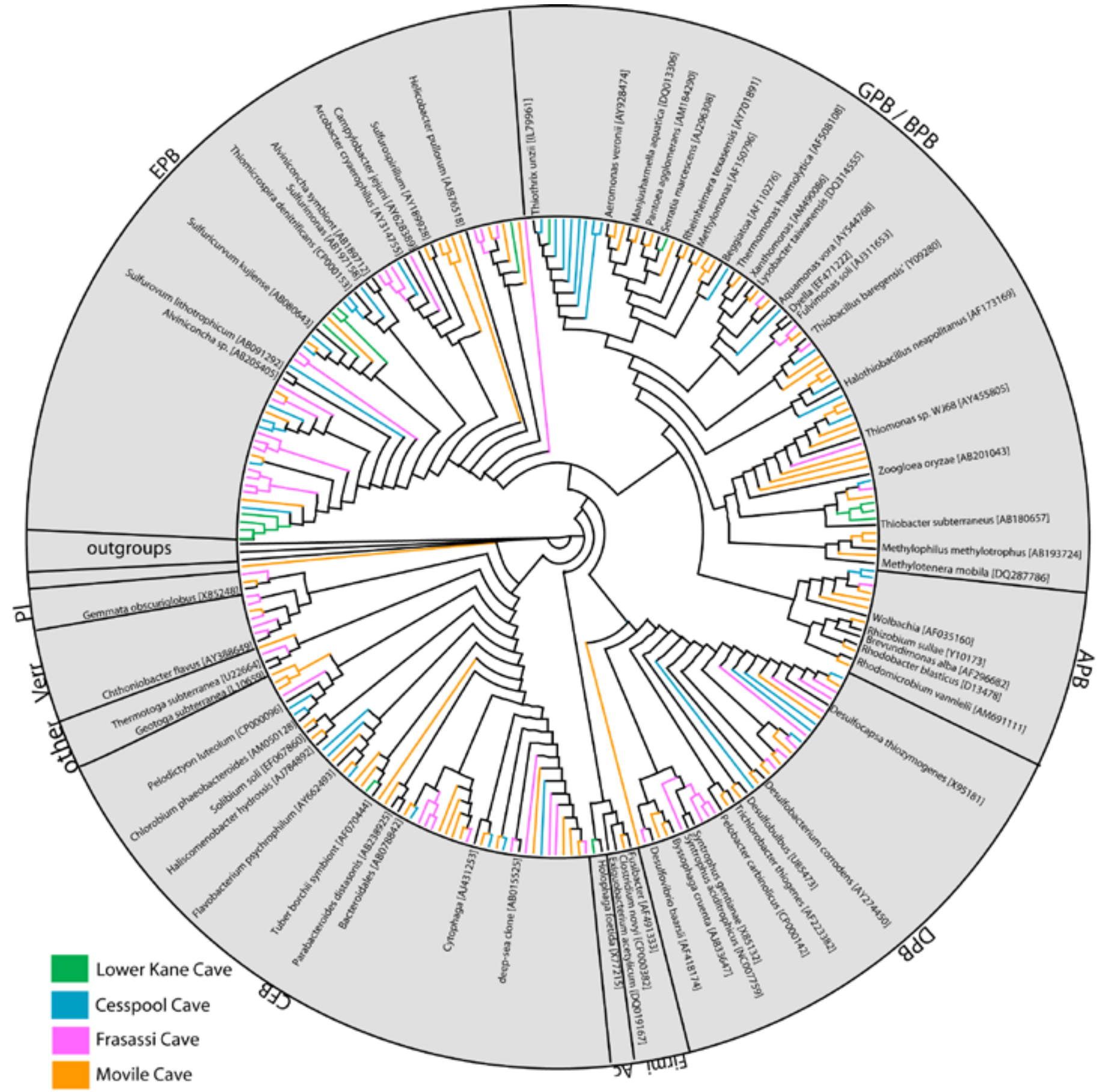

Fig. 4. Neighbor-joining phylogeny of a representative sequence for each site from each OTU, including the closest isolate to each sequence determined by Greengenes. Sequences representing OTUs from this study are colored according to location. Major groups are indicated as follows: $\mathrm{APB}=$ Alphaproteobacteria; $\mathrm{BPB}=$ Betaproteobacteria; $\mathrm{DPB}=$ Deltaproteobacteria; $\mathrm{EPB}=$ Epsilonproteobacteria; $\mathrm{GPB}=$

Gammaproteobacteria; $\mathrm{CFB}=$ Bacteroidetes $/$ Chlorobi group; Firmi = Firmicutes; $\mathrm{Ac}=$ Acidobacteria; $\mathrm{PI}=\mathrm{Planctomycetes}$; Verr = Verrucomicrobia; Other = candidate division SR1 and Nitrospirae. The tree was rooted using the following outgroups, Deinococcus geothermalis (Y13038) and Thermus aquaticus (L09663). 


\section{RESULTS}

\section{Field Observations and Physicochemistry}

White to faint yellow-colored, filamentous microbial mats were collected from all of the caves. The mats at Cesspool Cave were the thinnest, being $<1-2$ $\mathrm{mm}$ thick, and the most web-like in appearance. Discontinuous, white, webby filaments covered gray sediment. At Movile Cave, the samples were from the $\sim 3-4 \mathrm{~mm}$ thick floating mats from the airbells. The microbial mats in Lower Kane and the Frasassi Caves were the thickest, being 5-10 mm thick. These thicker mats were stratified, with yellowish patches and white filaments occurring at the air-water-mat surface, a gelatin-like white to light beige interior, and a dark gray to black layer at the sediment contact.

Each of the caves sampled was geochemically distinct, based on dissolved sulfide concentrations and conductivity (Table 1). The European caves had the highest dissolved sulfide values, with Lower Kane Cave having the lowest; this trend was similar for conductivity. Movile and Lower Kane Caves had higher temperatures compared to the other caves. All cave waters had circum-neutral $\mathrm{pH}$ and alkalinity values that are consistent with waters from caves and carbonate terrains.

\section{Microbial Community Productivity}

Because both the incubations and the previously reported RFLP clone library estimates of diversity in Lower Kane Cave were focused only on the aerobic, white filamentous components of the mat community, and did not include the anaerobic community from the mat interior, our estimates of $\left[{ }^{14} \mathrm{C}\right]$-leucine and $\left[{ }^{14} \mathrm{C}\right]$-acetate incorporations from Lower Kane Cave are not comparable to the other systems. Therefore, we only report autotrophic productivity for Lower Kane Cave. Autotrophic productivity from the $\left[{ }^{14} \mathrm{C}\right]-$ bicarbonate incorporation measurements was highest from Movile Cave and lowest from Cesspool Cave (Table 2). Autotrophic primary productivity was at least an order of magnitude greater than the measured heterotrophic activity in all systems. Incorporation measurements of $\left[{ }^{14} \mathrm{C}\right]$-acetate and $\left[{ }^{14} \mathrm{C}\right]$-leucine indicated that the thicker, stratified Frasassi Cave mats had the highest heterotrophic activities. The thinner mats of Cesspool and Movile Cave had lower activities for both compounds, with the floating mats from Movile Cave having the lowest rates (Table 2). An index of autotrophic to heterotrophic production can be calculated by comparing the rates of $\left[{ }^{14} \mathrm{C}\right]-$ bicarbonate incorporation to $\left[{ }^{14} \mathrm{C}\right]$-leucine estimates of incorporation. This index shows the excess of chemoautotrophy in each system relative to microbial heterotrophy, with Movile Cave having the highest index by two orders of magnitude (Table 2).

\section{Microbial Community Diversity and Abundance}

In this study we cloned and sequenced 414 new $16 \mathrm{~S}$ rRNA genes from sulfidic cave microbial communities. Based on the results from our current study, the cave microbial mats contained diverse bacterial communities that varied in composition, diversity, and richness (Figure 3). The rarefaction curves and richness estimators (Chao1 and $\mathrm{ACE}$ ) suggest that our sampling efforts for the Frasassi and Movile Caves did not match the predicted bacterial diversity for the cave communities (Figures $2 \& 3$ ). According to OTU designations at the $99 \%$ sequence identity level, Movile Cave had the highest number of OTUs, as well as the highest number of singletons and the highest diversity indices estimated among the caves (Figure 3).

Recognizing that our clone library screening was notexhaustive, we were able to recover representative distributions based on sequence abundance in each library of clones affiliated with eight major phyla (Figure 4), with the most abundant group being the Proteobacteria $(81 \%$ of the total number of clones). Among the classes of Proteobacteria, members of the Epsilonproteobacteria (37\%), Gammaproteobacteria (19\%), and Betaproteobacteria $(16 \%)$ comprised a significant proportion of the clone libraries (Figure 3). The Bacteroidetes/ Chlorobi were the most abundant (12\%) among the non-proteobacterial groups. Rare clones related to

Table 1. Physicochemical description of sulfidic cave sites.

\begin{tabular}{|c|c|c|c|c|c|c|c|c|}
\hline System & $\begin{array}{c}\text { Mat } \\
\text { Thickness }\end{array}$ & Temp & $\mathbf{p H}$ & Conductivity & $\mathbf{H}_{\mathbf{2}} \mathbf{S}$ & $\begin{array}{c}\text { Dissolved } \\
\text { Oxygen }\end{array}$ & Alkalinity & Reference \\
\hline & $\mathrm{mm}$ & ${ }^{\circ} \mathrm{C}$ & & $\mu \mathrm{S} / \mathrm{cm}$ & $\mu \mathrm{mol} / \mathrm{L}$ & $\mu \mathrm{mol} / \mathrm{L}$ & $\mathrm{mmol} / \mathrm{L}$ & \\
\hline Lower Kane Cave, Wyoming & $5-10$ & 23.6 & 7.2 & 575 & 39 & $<0.1$ & 3.4 & Engel et al. (2004) \\
\hline Cesspool Cave, Virginia & $<1-2$ & 12.2 & 6.8 & 600 & 50 & -- & 6.3 & Hubbard et al. (1990) \\
\hline Frasassi Caves, Italy & $5-10$ & 13.6 & 7.5 & 1870 & 188 & 6.8 & 4.3 & Engel, unpub. data \\
\hline Movile Cave, Romania & $3-4$ & 20.8 & 7.3 & 1443 & 240 & $<0.1$ & 6.7 & Badescu (1998) \\
\hline
\end{tabular}

Table 2. Summary of biomass production ( $\mu \mathrm{g} \mathrm{C} / \mathrm{mgdw} / \mathrm{hr}$ ) for chemolithoautotrophic and heterotrophic and chemoorganotrophic metabolisms from sulfidic karst environments.

\begin{tabular}{|c|c|c|c|c|}
\hline Ecosystem & ${ }^{14} \mathrm{C}$-Bicarbonate & ${ }^{14} \mathrm{C}$-Leucine & ${ }^{14} \mathrm{C}$-Acetate & Bicarbonate / Leucine \\
\hline Cesspool Cave & $0.03 \pm 0.01$ & $1.7 \times 10^{-4} \pm 2.5 \times 10^{-5}$ & $9.3 \times 10^{-5} \pm 2.0 \times 10^{-7}$ & 176.5 \\
\hline Lower Kane Cave & $0.10 \pm 0.01$ & $\mathrm{NM}$ & $\mathrm{NM}$ & -- \\
\hline Frasassi Cave & $1.01 \pm 0.47$ & $1.5 \times 10^{-2} \pm 4.1 \times 10^{-3}$ & $7.6 \times 10^{-4} \pm 1.0 \times 10^{-5}$ & 67.3 \\
\hline Movile Cave & $4.72 \pm 0.78$ & $5.5 \times 10^{-5} \pm 5.3 \times 10^{-5}$ & $4.1 \times 10^{-5} \pm 3.5 \times 10^{-7}$ & 85454.5 \\
\hline
\end{tabular}




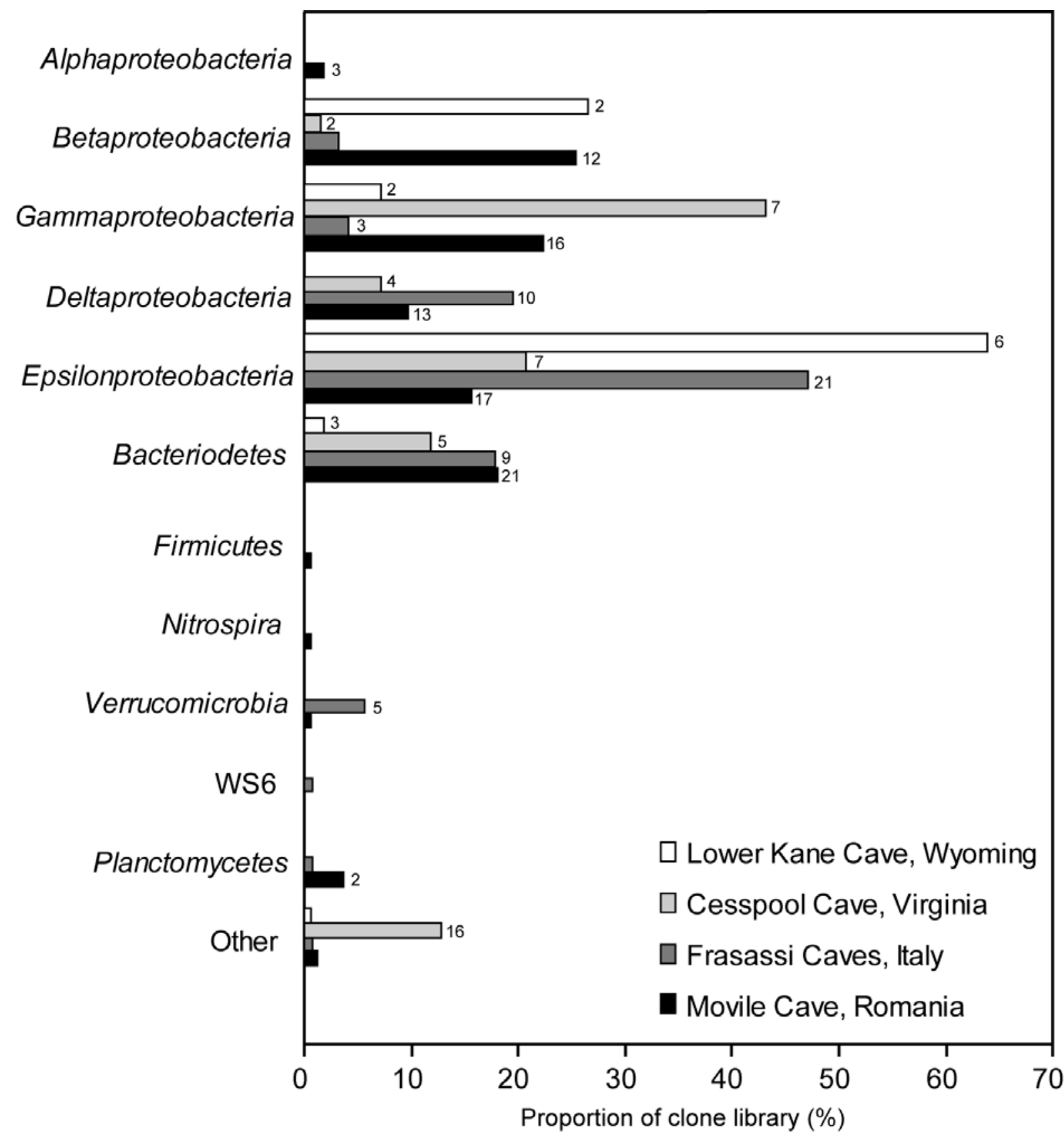

\begin{tabular}{|c|c|c|c|c|c|c|c|}
\hline Cave & $\begin{array}{c}\text { No. of } \\
\text { sequences }\end{array}$ & $\begin{array}{l}\text { No. of } \\
\text { OTUs }^{a}\end{array}$ & $\begin{array}{c}\text { No. of } \\
\text { singletons }\end{array}$ & Chao1 & ACE & $\begin{array}{l}\text { Shannon - } \\
\text { Weiner } \\
\text { Index }\end{array}$ & $\begin{array}{l}\text { Simpson's } \\
\text { Index }\end{array}$ \\
\hline Lower Kane Cave, Wyoming & $166^{b}$ & $10^{6}$ & $3^{6}$ & $--^{c}$ & $--^{c}$ & $--^{c}$ & $--^{c}$ \\
\hline Cesspool Cave, Virginia & 125 & 42 & 28 & 140 & 117.6 & 2.9 & 8.9 \\
\hline Frasassi Caves, Italy & 124 & 55 & 39 & 198.4 & 171.2 & 3.5 & 26.7 \\
\hline Movile Cave, Romania & 165 & 88 & 61 & 215.6 & 205 & 4.0 & 34.7 \\
\hline
\end{tabular}

${ }^{\mathrm{a}}$ OTUs defined as $1 \%$ difference in 16S rRNA sequence

${ }^{b}$ Sequences from restriction fragment length polymorphism (RFLP) study, Engel et al. (2004)

c--, Estimates of richness or diversity were not calculated from RFLP data

Fig. 3. Proportion of bacterial groups within clone libraries obtained from cave microbial mats. Numbers after bars represent the number of OTUs (>1) per taxonomic group. The table lists the diversity indices for the sequences retrieved from the caves. Estimates of richness were calculated according to the abundance-based coverage estimate (ACE) and the classic form Chao1 estimator. The Shannon-Weiner Index accounts for species richness and evenness, and the Simpson's Index estimates the evenness of the population. 
the Alphaproteobacteria, Firmicutes, Nitrospirae, Planctomycetes, Verrucomicrobia, Acidobacteria, and to the candidate divisions WS6 and SR1 were also retrieved. The recovered OTUs found within each cave community are distributed throughout each major phyla, across a broad taxonomic sampling, with few OTUs clustering by site (Figure 4).

At the 99\% sequence identity level, no OTU was identified from all four caves. Only three OTUs were found in three caves, correlating to two OTUs affiliated with the Gammaproteobacteria and one OTU affiliated with the Betaproteobacteria. The largest OTU, consisting of 40 clones from three caves (Lower Kane, Cesspool, and Movile Caves), was closely related to Thiothrix unzii [L79961] (99\% sequence identity) (Figure 4). Even though Thiothrix spp. have been identified from the Frasassi Caves (Macalady et al., 2006; Macalady et al., 2008), sequences from this OTU were only 95\% identical to the sequences previously retrieved from this system. The other gammaproteobacterial OTU, comprised of sequences from Cesspool, Frasassi, and Movile Caves, was closely related (97-98\% sequence identity) to sequences retrieved from the Frasassi Caves that have been classified as the "Thiovirga" group because of their affinity to Thiovirga sulfuroxydans [AB118236] (Macalady et al., 2006; Macalady et al., 2008). The betaproteobacterial OTU, identified from the Cesspool, Frasassi, and Movile Caves, was closely related (98-99\% sequence identity) to clones previously retrieved from the Frasassi Caves (Macalady et al., 2006; Macalady et al., 2008), including clones from the acidic cave-wall biofilms (Macalady et al., 2007), as well as to clones retrieved from acid mine drainage and compost. This group is associated with the Hydrogenophilaceae, and is most closely related to Candidatus "Thiobacillus baregensis" (Figure 4).

Twenty OTUs at the 99\% similarity level were found from at least two caves. Thirteen OTUs, consisting of 71 total clones, were identified from both the Frasassi and Movile Caves. Five of the groups were associated with the Epsilonproteobacteria. These groups were related to clone sequences previously retrieved from Lower Kane and Cesspool Caves, although sequence similarities were 95-97\%. Six OTUs were identified from sequences retrieved from Cesspool and Movile Caves, and one OTU each was identified from the Lower Kane and Cesspool Caves and from the Lower Kane and Movile Caves.

Nearly $64 \%$ of the clone sequences were placed into 147 OTUs that were retrieved from only one cave. The lack of overlap among a large percentage of clones from the libraries was verified using webLIBSHUFF to test for statistical differences between 16S rRNA clone libraries. Because the Lower Kane Cave libraries were generated from RFLP analyses, only the Cesspool, Frasassi, and Movile Cave clone libraries were evaluated (data not shown). Even though there was overlap among some OTUs (e.g,. those affiliated with the Gammaproteobacteria, Betaproteobacteria, and Epsilonproteobacteria), all of the library comparisons (i.e. Cesspool to Frasassi, Cesspool to Movile, and Frasassi to Movile) had $P$ values of $\leq 0.001$, indicating that all of the communities were comprised of distinct populations.

\section{DISCUSSION}

\section{Productivity in Chemolithoautotrophic Subterranean Microbial Communities}

Despite widespread recognition of chemolithoautotrophic metabolism in a variety of habitats, from deep-sea hydrothermal vents to caves, it is still unclear how these microbial communities function in situ for most ecosystems, or how much potential there is for chemolithoautotrophy to support higher trophic levels. The rate of primary productivity, in particular, is a crucial driver of ecosystem dynamics that can affect the length and complexity of the food chain (e.g., Pimm, 1988; Lampert \& Sømmer, 1997; Naeem, 2002). Ecosystems energetically dependent on chemolithoautotrophic production were first discovered over thirty years ago, but our understanding of energetic dynamics in these communities is still rudimentary. Specifically, the highest estimated rate of chemolithoautotrophic productivity from our study was Movile Cave (281 g $\mathrm{C} / \mathrm{m}^{2} / \mathrm{yr}$ ). This rate is comparable to those estimated from sulfidic springs at Cape Palinuro, Italy (378 g C/ $\mathrm{m}^{2} / \mathrm{yr}$ ) (Mattison et al., 1998), as well as the hyporheic zone of Sycamore Creek, Arizona (333 g C/m²/yr) (Jones et al., 1994), and autotrophic productivity estimates from open oceans, continental shelves, and upwelling zones, as well as lakes and streams (Lieth, 1972; Kirchman et al., 1993).

\section{Diversity in Chemolithoautotrophic Subterranean Microbial Communities}

The microbial communities from Cesspool, Movile, and Frasassi Caves had been previously investigated at varying levels, but none of the studies obtained $16 \mathrm{~S}$ rRNA gene sequences that could be directly correlated to the locations and times where we conducted the incorporation experiments (Sarbu et al., 1996; Vlasceanu et al., 1997; Vlasceanu, 1999; Sarbu et al., 2000; Vlasceanu et al., 2000; Engel et al., 2001; Hutchens et al., 2004; Macalady et al., 2006; Macalady et al., 2008). Therefore, clone libraries were constructed from microbial mats from these three caves to evaluate the evolutionary relationships among the bacterial communities directly associated with chemolithoautotrophic primary productivity. We did not construct a new clone library for Lower Kane Cave because the microbial mat bacterial diversity has been recently described to be predominately aerobic, uncultured groups of Epsilonproteobacteria, Thiothrix spp., Thiobacillus spp., Acidobacteria, and a range of aerobic to facultative heterotrophs at the surface of the mats covering a complex anaerobic interior of diverse anaerobes, including sulfate-reducers, Chloroflexi, and fermenting bacteria (Engel et al., 2003; Engel et al., 2004; Meisinger et al., 2007; Engel et al., 2008). 


\section{Productivity-Diversity Relationships}

One of our goals was to compare primary productivity and carbon cycling from radiotracer incorporation experiments within and among microbial communities that we characterized phylogenetically. One of the limitations to applying macro-ecological principles to microbial systems is that we can only speculate as to the metabolic potential (function) of uncultured, novel microbial groups (e.g., Kaunzinger \& Morin, 1998; Horner-Devine et al., 2003; Smith, 2007). Because we know that phylogeny does not reveal function, bacterial species diversity and functional diversity may not be equivalent values (e.g., Acinas et al., 2004). We retrieved a broad phylogenetic distribution for OTUs from the caves, and all of the communities were found to be unique in species composition (i.e. OTU diversity). But, for some of the most prevalent microbial groups in each of the systems, we conservatively suggest that function, at least for some processes, is comparable (e.g., sulfur oxidation, sulfate reduction).

Therefore, at the most basic level of interpretation, we wanted to consider if the rates of productivity that were measured could be linked to diversity in the cave ecosystems. Our estimates of autotrophic productivity from each cave were positively correlated $\left(R^{2}=0.62\right.$; $P \leq 0.03$ ) with overall OTU diversity (Figure 5A), and were also positively correlated to the overall numbers of OTUs affiliated with the Epsilonproteobacteria $\left(\mathrm{R}^{2}=\right.$ $0.70 ; P \leq 0.05)$. The regression correlation coefficients from the productivity results and the number of OTUs associated with the Deltaproteobacteria $\left(\mathrm{R}^{2}=\right.$ 0.76; $P \leq 0.08$ ) and the Bacteriodetes/Chlorobi group $\left(\mathrm{R}^{2}=0.75 ; P \leq 0.11\right)$ were high but not statistically significant. No other discernable, statistically significant patterns for the other major taxonomic groups were found (data not shown). These correlations suggest a tight link between autotrophy, both as carbon fixation and resource availability, and sulfur cycling. However, these monotonic (positive or negative) relationships may also represent only a fraction of the productivity-diversity relationships that exist in these chemolithoautotrophically based karst systems (e.g., as reviewed in Abrams, 1995; Smith, 2007). We cannot rule out the fact that more experiments could be done that might show a hump-shaped relationship, indicating decreased diversity with even higher rates of productivity. Nevertheless, considering all of the ecosystem parameters for the four cave systems (e.g., trophic levels, numbers of stygobites and troglobites, relative ages of the caves, etc.), we contend that some of the explanations of Abrams (1995) interpreting positive (monotonic) relationships are valid for our results.

First, increased productivity can support higher numbers of rarer species in a community based on increased resource density. These rarer species would have larger populations at higher productivity rates instead of going undetected due to smaller population sizes in systems with lower productivity. In our study, this is true at both the macro- and micro- scales. The cave ecosystems with the highest rates of chemolithoautotrophy also contain the most abundant, diverse, and complex food webs of macro-
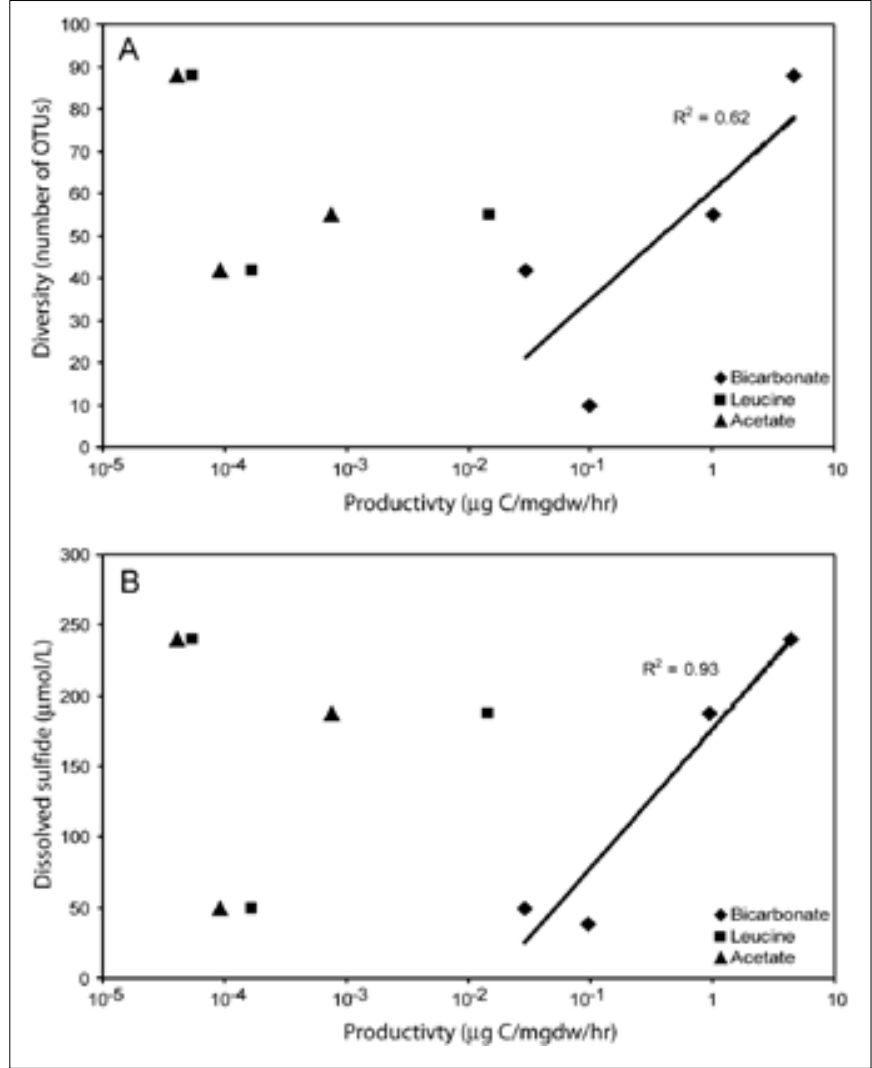

Fig. 5. (Panel A) The relationship between primary and heterotrophic productivity and diversity, as operational taxonomic units (OTUs), of bacteria from four sulfidic cave microbial communities. (Panel B) The relationship between primary and heterotrophic productivity and the concentration of dissolved sulfide. In both panels, primary productivity was estimated from $\left[{ }^{14} \mathrm{C}\right]$-bicarbonate incorporation (solid diamonds) and heterotrophic productivity was estimated from $\left[{ }^{14} \mathrm{C}\right]$-leucine (solid squares) and $\left[{ }^{14} \mathrm{C}\right]$-acetate (solid triangles) incorporation. The line, and associated $\mathrm{R}^{2}$ value, represents the correlation analysis for the relationship between primary productivity and either diversity (Panel A) or dissolved sulfide (Panel B).

invertebrates based on the current faunal inventory datasets (Sarbu et al., 1996; Popa, 1997; Sarbu et al., 2000; Engel, 2007). Within the microbial communities, Movile Cave had the highest number of singletons based on the number of OTUs retrieved from our study (Figure 3), supporting the occurrence of rare species being linked to productivity. Furthermore, the phylogenetic distribution of the OTUs across a large taxonomic distance indicates that higher productivity supports communities of more distantly related taxa, similar to previous studies of Betaproteobacteria (Horner-Devine \& Bohannan, 2006). These trends stress the importance of microbial productivity in controlling the structure of higher trophic levels (Lennon \& Cottingham, 2008).

Similarly, increased productivity could increase the availability of resources, including rarer resources, that would increase niche specialization, and therefore specialist species, or even generalists that were inferior competitors (Abrams, 1995). The increase in Bacteroidetes/Chlorobi OTUs with increased autotrophic productivity may directly support these results. Higher productivity would allow for the existence of species having niche overlap because 
resources could be unlimited. Recently, Macalady et al. (2008) proposed niche differentiation in sulfidic cave waters due to spatial arrangement in sulfide and dissolved oxygen gradients for some of the same microbial groups that we identified in this study (e.g., Epsilonproteobacteria and Gammaproteobacteria closely related to Thiothrix spp. and Beggiatoa spp.). The interactions between niche overlap and differentiation are not well understood in microbial systems and require further study.

\section{Productivity-diversity relationship and environmental energy sources}

Because the productivity-diversity relationships strongly correlated to specific phylogenetic groups associated with sulfur cycling, the higher autotrophic productivity rates could also be correlated to resource availability, and specifically to energy input needed for chemolithoautotrophy. As a first pass to compare environmental geochemistry to microbial productivity, we compared primary productivity to dissolved sulfide concentrations (Figure 5B). There was a strong, positive correlation $\left(\mathrm{R}^{2}=0.93 ; P \leq 0.04\right)$, further supporting a tight link between the carbon and sulfur cycles in the caves.

From an energetics perspective, dissolved sulfide serves as one of the most energetic substrates for oxidative metabolism. Sulfide can also be generated in situ by dissimilatory sulfate reduction within the microbial mat communities, both chemolithoautotrophically and chemoorganotrophically using acetate. Dissolved sulfide concentrations can also be augmented through disproportionation of sulfur compounds of intermediate oxidation states, and several phylogenetic groups known for sulfur disproportionation were identified in the caves (e.g., Desulfocapsa thiozymogenes) (Figure 4).

While the positive correlation for OTU numbers from the Epsilonproteobacteria, who would likely be oxidizing the sulfide, can be explained by their overwhelming prevalence in some systems (Figure 3), the possible association between deltaproteobacterial OTU diversity and $\left[{ }^{14} \mathrm{C}\right]$-bicarbonate incorporation rates might be linked to autotrophy because the Deltaproteobacteria (1) play a direct role in autotrophic productivity by either being capable of chemolithoautotrophic carbon fixation, or (2) are directly dependent on the products of autotrophic productivity for their growth. Therefore, the differences in rates of primary productivity (Table 2) may be attributed to the availability of reduced sulfur compounds in each of the caves (Figure 5B), which in turn could promote diversity among sulfur-oxidizing, chemolithoautotrophic microbial groups and increased diversity among chemoorganotrophs and heterotrophs dependent on the autotrophically-fixed carbon, such as the sulfate-reducing prokaryotes.

Other microbial groups are known to cycle sulfur compounds, including some members from the other classes within the Proteobacteria, and the Verrucomicrobia and Planctomycetes phyla (albeit, the sulfur-based metabolisms of these groups in caves, and dark habitats in general, have been understudied). Representatives from these major phyla were identified in all of the cave systems, either from our results or previous work (Engel et al., 2004; Macalady et al., 2006; Macalady et al., 2008) (Figure 4), but the numbers of these groups did not strongly correlate with autotrophy rates, dissolved sulfide (or other geochemical parameters), or even to the incorporation rates for heterotrophy. This suggests that the link among productivity, carbon cycling, and bacterial diversity in the microbial communities that we examined is more complicated than the current dataset can resolve, and that more work is needed to address specifically the functional roles of these other groups.

The phylogenetic affinities of some of the microbial groups from our 16S rRNA gene sequence clone libraries highlight that other, non sulfur-oxidizing, chemolithoautotrophic metabolic groups might be present (Figure 4), and we recognize that other autotrophic, energy-yielding pathways are possible (e.g., Kuenen \& Bos, 1989; Stevens, 1997; Kinkle \& Kane, 2000). Aerobic chemolithoautotrophic processes, where oxygen is used as the electron acceptor, are more energetic than anaerobic processes. But, alternative electron acceptors, such as nitrate, can also be used for energy conservation, and anaerobic chemolithoautotrophy, including methanogenesis, is also possible. If there is a link between $\mathrm{H}_{2} \mathrm{~S}$ oxidation and nitrate reduction, a pathway that some Epsilonproteobacteria are capable of, then this may be reflected in our data for the correlations among epsilonproteobacterial diversity, primary productivity, and $\mathrm{H}_{2} \mathrm{~S}$ concentrations. Furthermore, electron donors for chemolithoautotrophy can include reduced sulfur compounds, molecular hydrogen, carbon monoxide, reduced nitrogen compounds, $\mathrm{Fe}^{2+}, \mathrm{Mn}^{2+}$, and possibly other transition metals. We did not explicitly examine the diversity of Archaea in our study, but because recent research has indicated that methane cycling may be significant in karst aquifers (e.g., Opsahl \& Chanton, 2006) and other groundwater systems (e.g., Stevens \& McKinley, 1995; Chapelle et al., 2002), future work should thoroughly investigate archaeal diversity in conjunction with bacterial diversity, especially related to methane cycling.

\section{Habitat Heterogeneity and Heterotrophic Cycling}

There were no detectable correlations (random pattern; Abrams, 1995) between $\left[{ }^{14} \mathrm{C}\right]$-leucine and $\left[{ }^{14} \mathrm{C}\right]-$ acetate incorporation rates and overall OTU diversity (Figure 5A), as well as to dissolved sulfide concentrations (Figure 5B). It is possible that heterotrophic cyclingdiversity relationships are linked to specific taxonomic groups that were not evident in our current dataset (e.g., Horner-Devine et al., 2003), and only additional work will resolve this issue. However, we suggest that the overall distribution patterns of heterotrophic and chemoorganotrophic metabolic groups, and specifically stratification of populations within the mat systems, may explain why the $\left[{ }^{14} \mathrm{C}\right]$-leucine and $\left[{ }^{14} \mathrm{C}\right]$-acetate incorporation rates show no strong correlations with OTU diversity (Figure 5A). 
All of the microbial communities investigated from the standpoint of heterotrophic productivity had strikingly different structure, including floating mats (Movile Cave), thin discontinuous webs (Cesspool Cave), and thick stratified mats (Frasassi Caves). The physical structure of the microbial community influences the availability of anaerobic niches close to the site of autotrophic productivity, which affects the efficiency of carbon and sulfur cycling among heterotrophic and autotrophic guilds. The structure of the mat, therefore, controls the flow of material and energy among microbial populations, which greatly impacts the production and respiration of organic matter (Lennon \& Cottingham, 2008).

For example, in Movile Cave the floating mat undergoes a net loss of detrital organic carbon because the community in this mat is physically separated from other components of the microbial ecosystem. As the lower portions of floating mat die, the material detaches and sinks to the sediment nearly $1 \mathrm{~m}$ below the air-water interface (Popa, 1997; Vlasceanu, 1999). This separation may be reflected in the high ratio of autotrophic to heterotrophic productivity for the sample that we used in our incubation experiments (Table 2), and suggests that the majority of the heterotrophic and chemoorganotrophic activities in the Movile Cave ecosystem are likely separated from the source of chemolithoautotrophy. In comparison, the spatially proximate autotrophic and heterotrophic populations in the more stratified, and potentially niche-partitioned, mat community in Frasassi Caves (e.g., Macalady et al., 2008) contained the highest rates of $\left[{ }^{14} \mathrm{C}\right]$ - leucine and $\left[{ }^{14} \mathrm{C}\right]$-acetate incorporation (Table 2).

\section{SUMMARY}

In this investigation, we focused on sulfidic cave systems and found that the rate of primary productivity directly correlates with bacterial species diversity, which is likely driven by the availability of reduced sulfur compounds. Sulfidic environments occur around the world, including both thermal and non-thermal sulfur springs and pools, groundwater aquifers, caves, and hydrothermal vents and seeps. The recent discovery of the diverse, endemic fauna from Ayalon Cave, Israel (Por, 2007), is testament to the fact that chemolithoautotrophic karst systems are more prevalent than currently recognized. This prevalence, in conjunction with the estimates of microbial activity from this research, indicates that chemolithoautotrophy is ecologically significant in terrestrial karst systems. Although we recognize that chemolithoautotrophy may be potentially important to global primary productivity, biomass, and biogeochemical cycles (e.g., Schlesinger, 1991), particularly because only a fraction of the earth's biomass can be supported by photosynthetically produced material (e.g., Whitman et al., 1998), more studies of chemolithoautotrophic ecosystems are needed. Cave and karst systems allow for direct access to the site of productivity, and so the next step in cave and karst ecosystem energetic studies would be to determine if the productivity rate estimates are sufficient to sustain ecosystem level processes, as well as food chain length and trophic structure.

\section{ACKNOWLEDGEMENTS}

The initial stages of the research were supported in part by research grants to M.L.P from the National Speleological Society and the University of Cincinnati, and a National Science Foundation grant (DEB9420033) to T.C. Kane and B.K. Kinkle. Continued support was provided from the Louisiana Board of Regents Support Fund (Contract NSF/LEQSF(2005)Pfund-04) and the National Science Foundation (DEB-0640835) to A.S.E. We gratefully acknowledge the assistance of R. Popa and S. Sarbu for work in Movile Cave, and M. Menichetti for efforts in the Frasassi Caves. The Bureau of Land Management provided permission for work in Lower Kane Cave. The manuscript benefited from the comments of $\mathrm{E}$. Hutchens and an anonymous reviewer.

\section{REFERENCES}

Abrams P. A., 1995 - Monotonic or unimodal diversityproductivity gradients: what does competition theory predict? Ecology, 76: 2019-2027.

Acinas S. G., Klepac-Ceraj V., Hunt,D. E., Pharino C., Ceraj I., Distel D. L. \& Polz M. F., 2004 - Fine-scale phylogenetic architecture of a complex bacterial community. Nature, 430: 551-554.

Azam F., Smith D. C., Steward G. F. \& Hagström Å., 1993 - Bacteria-organic matter coupling and its significance for oceanic carbon cycling. Microbial Ecology, 28: 167-179.

Bachofen R., Ferloni P. \& Flynn I., 1998 - Microorganisms in the subsurface. Microbiological Research, 153: 1-22.

Badescu A. C., 1998 - Isotope geochemistry in the Movile Cave aquifer system: a southern source of water and reduced sulfur. M.S. Thesis: Cincinnati, University of Cincinnati, $139 \mathrm{p}$.

Barton H. A., Taylor N. M., Kreate M. P., Springer A. C., Oehrle S. A. \& Bertog J. L., 2007 - The impact of host rock geochemistry on bacterial community structure in oligotrophic cave environments. International Journal of Speleology, 36: 93-104.

Brown A. V., Pierson W. K. \& Brown K. B., 1994 Organic carbon and the payoff-risk relationship in cave ecosystems. 2nd International Conference on Ground Water Ecology: 67-76.

Castresana J., 2000 - Selection of conserved blocks from multiple alignments for their use in phylogenetic analysis. Molecular Biology and Evolution, 17: 540552.

Chapelle F. H., O’Neil K. O., Bradley P. M., Methe B. A., Ciufo S. A., Knobel L. L. \& Lovley D. R., 2002 A hydrogen-based subsurface microbial community dominated by methanogens. Nature, 415: 312-315.

Chesson P., Pacala S. W. \& Neuhauser C., 2002 Enviromental niches and ecosystem functioning. In: Kinzig A. P., Pacala S. W. \& Tilman D. (Eds.). The Functional Consequences of Biodiversity: Monographs in Population Biology: 213-245. 
Culver D. \& Sket B., 2000 - Hotspots of subterranean biodiversity in caves and wells. Journal of Cave and Karst Studies, 62: 11-17.

Deming J. \& Baross J., 1993 - Deep-sea smokers: windows to a subsurface biosphere. Geochimica et Cosmochimica Acta, 57: 3219-3230.

DeSantis T. Z., Hugenholtz P., Keller K., Brodie E. L., Larsen N., Piceno Y. M., Phan R. \& Andersen G. L., 2006a - NAST: a multiple sequence alignment server for comparative analysis of 16S rRNA genes. Nucleic Acids Research, 34: W394-W399.

DeSantis T. Z., Hugenholtz P., Larsen N., Rojas M., Brodie E. L., Keller K., Huber T., Dalevi D., Hu P. \& Andersen G. L., 2006b - Greengenes, a chimera-checked 16S rRNA gene database and workbench compatible with $A R B$. Applied and Environmental Microbiology, 72: 5069-5072.

Díaz-Raviña M. \& Bååth E., 1996 - Thymidine and leucine incorporation into bacteria from soils experimentally contaminated with heavy metals. Applied Soil Ecology, 3: 225-234.

Engel A. S., 2007 - Observations on the biodiversity of sulfidic karst habitats. Journal of Cave and Karst Studies, 69: 187-206.

Engel A. S., Lee N., Porter M. L., Stern L. A., Bennett P. C. \& Wagner M., 2003 - Filamentous "Epsilonproteobacteria" dominate microbial mats from sulfidic cave springs. Applied and Environmental Microbiology, 69: 55035511.

Engel A. S., Lichtenberg H., Prange A. \& Hormes J., 2007 - Speciation of sulfur from filamentous microbial mats from sulfidic cave springs using X-ray absorption near edge spectroscopy. FEMS Microbiology Letters, 269: 54-62.

Engel A. S., Meisinger D. B., Porter M. L., Schmid M., Stern L. A. \& Lee N., 2008 - Anaerobic microbial diversity in redox-stratified microbial mats: the basis for nutrient spiraling in a chemolithoautotrophic ecosystem. The ISME Journal (in press).

Engel A. S., Porter M. L., Kinkle B. K. \& Kane T. C., 2001 - Ecological assessment and geological significance of microbial communities from Cesspool Cave, Virginia. Geomicrobiology Journal, 18: 259-274.

Engel A. S., Porter M. L., Stern L. A., Quinlan S. \& Bennett P. C., 2004 - Bacterial diversity and ecosystem function of filamentous microbial mats from aphotic (cave) sulfidic springs dominated by chemolithoautotrophic "Epsilonproteobacteria". FEMS Microbiology Ecology, 51: 31-53.

Felsenstein J., 1989 - PHYLIP - Phylogeny inference package (v 3.2). Cladistics 5: 164-166.

Findlay R. H., Pollard P. C., Moriarty D. J. W. \& White D. C., 1985 - Quantitative determination of microbial activity and community nutritional status in estuarine sediments: evidence for a disturbance artifact. Canadian Journal of Microbiology, 31: 493-498.

Fukami T. \& Morin P. J., 2003 - Productivity-biodiversity relationships depend on the history of the community assembly. Nature, 424: 423-426.

Galdenzi S. \& Menichetti M., 1995 - Occurrence of hypogenic caves in a karst region: examples from Central Italy. Environmental Geology, 26: 39-47.
Gevers D., Cohan F. M., Lawrence J. G., Spratt B. G., Coenye T., Feil E. J., Stackebrandt E., Van De Peer Y., Vandamme P., Thompson F. L. \& Swings J., 2005 - Opinion: Re-evaluating prokaryotic species. Nature Reviews Microbiology, 3: 733-739.

Horner-Devine M. C., Leibold M. A., Smith V. H. \& Bohannan B. J. M., 2003 - Bacterial diversity patterns along a gradient of primary productivity. Ecology Letters, 6: 613-622.

Horner-Devine M. C., \& Bohannan B. J. M., 2006 Phylogenetic clustering and overdispersion in bacterial communities. Ecology, 87: S100-S108.

Hubbard D. A., Herman J. S. \& Bell P. E., 1990 Speleogenesis in a travertine scarp: observations of sulfide oxidation in the subsurface. In: Herman J. S., Hubbard D.A. (Ed.). Travertine-Marl: Stream Deposits in Virginia: Charlottesville, Department of Mines, Minerals and Energy, Division of Mineral Resources: 177-184.

Hutchens E., Radajewski S., Dumont M. G., McDonald I. R. \& Murrell J. C., 2004 - Analysis of methanotrophic bacteria in Movile Cave by stable isotope probing. Environmental Microbiology, 6: 111-120.

Jones J. B., Holmes R. M., Fisher S. G. \& Grimm N. B., 1994 - Chemoautotrophic production and respiration in the hyporheic zone of a sonoran desert stream. Second International Conference on Groundwater Ecology: 329-337.

Jørgensen N., 1992 - Incorporation of [ ${ }^{3}$ Hlleucine and $\left[{ }^{3} \mathrm{H}\right]$ valine into protein of freshwater bacteria: Uptake kinetics and intracellular isotope dilution. Applied and Environmental Microbiology, 58: 3638-3646.

Kaunzinger C.M.K. \& Morin P.J., 1998 - Productivity controlsfood-chain properties in microbialcommunities. Nature, 395: 495-497.

Katoh K., Kuma K., Toh H. \& Miyata T., 2005 - MAFFT version 5: improvement in accuracy of multiple sequence alignment Nucleic Acids Research, 33: 511518.

Katoh K., Misawa K., Kuma K. \& Miyata T., 2002 MAFFT: a novel method for rapid multiple sequence alignment based on fast Fourier transform (describes the FFT-NS-1, FFT-NS-2 and FFT-NS-i strategies). Nucleic Acids Research, 30: 3059-3066.

Kelly D. P., 1967 - The incorporation of acetate by the chemoautotroph Thiobacillus neapolitanus strain $C$. Archives of Microbiology, 58: 99-116.

Kinkle B. \& Kane T. C., 2000 - Chemolithoautotrophic micro-organisms and their potential role in subsurface environments. In: Wilkens H., Culver D.C. \& Humphreys W.F. (Eds.). Ecosystems of the World 30: Amsterdam, Elsevier: 309-318.

Kirchman D., K’Nees E. \& Hodson R., 1985 - Leucine incorporation and its potential as a measure of protein synthesis by bacteria in natural aquatic systems. Applied and Environmental Microbiology, 49: 599607.

Kirchman D. L., 1993 - Leucine incorporation as a measure of biomass production by heterotrophic bacteria. In: Kemp P. F., Sherr B. F., Sherr E. B. \& Cole J. J. (Eds.). Handbook of Methods in Aquatic Microbial Ecology, Lewis Publishers: 509-512. 
Kirchman D. L., Keil R. G., Simon M. \& Welschmeyer N. A., 1993 - Biomass and production of heterotrophic bacterioplankton in the oceanic subarctic Pacific. DeepSea Research, 40: 967-988.

Kuenen J. G. \& Bos P., 1989 - Habitats and ecological niches of chemolitho(auto)trophic bacteria. In: Schlegel H. G. \& Bowien B. (Eds.). Autotrophic Bacteria: Madison, Science Tech Publishers: 53-80.

Lampert W. \& Sømmer U., 1997 - Limnoecology: The ecology of lakes and streams. Oxford University Press, New York: 382p.

Lennon J. T., \& Cottingham K. L., 2008 - Microbial productivity in variable resource environments. Ecology, 89: 1001-1014.

Lieth H., 1972 - Modelling the primary productivity of the world. Nature and Resources, 8: 5-10.

Macalady J. L., Dattagupta S., Schaperdoth I., Jones D. S., Druschel G. K. \& Eastman D., 2008 - Niche differentiation among sulfur-oxidizing bacterial populations in cave waters. The ISME Journal, Advance online publication, March 20, 2008; doi:10.1038/ ismej.2008.25.

Macalady J. L., Jones D. S. \& Lyon E. H., 2007 - Extremely acidic, pendulous cave wall biofilms from the Frasassi cave system, Italy. Environmental Microbiology, 9: 1402-1414.

Macalady J. L., Lyon E.H., Koffman B., Albertson L. K., Meyer K., Galdenzi S. \& Mariani S., 2006 - Dominant microbial populations in limestone-corroding stream biofilms, Frasassi cave system, Italy. Applied and Environmental Microbiology, 72: 5596-5609.

Mattison R., Abbiati M., Dando P., Fitzsimons M., Pratt S., Southward A. \& Southward E., 1998 Chemoautotrophic microbial mats in submarine caves with hydrothermal sulphic springs at Cape Palinuro, Italy. Microbial Ecology, 35: 58-71.

McCann K. S., 2000 - The diversity-stability debate. Nature, 405: 228-233.

Meisinger D. B., Zimmermann J., Ludwig, W., Schleifer K.-H., Wanner G., Schmid M., Bennett P. C., Engel A. S. \& Lee N. M., 2007 - In situ detection of novel Acidobacteria in microbial mats from a chemolithoautotrophically based cave ecosystem (Lower Kane Cave, WY, USA). Environmental Microbiology, 9: 1523-1534.

Munro A. L. S. \& Brock T. D., 1968 - Distinction between bacterial and algal utilization of soluble substances in the sea. Journal of General Microbiology, 51: 35-42.

Naeem S., 2002 - Autotrophic-heterotrophicinteractions and their impacts on biodiversity and ecosystem functioning. In: Kinzig A. P., Pacala S. W. \& Tilman D. (Eds.). The Functional Consequences of Biodiversity: Empirical progress and theoretical extensions. Monographs in Population Biology 33: Princeton, Princeton University Press.

Naeem S. \& Li S., 1998 - Consumer species richness and autotrophic biomass. Ecology, 79: 2603-2615.

Opsahl S. P. \& Chanton J. P., 2006 - Isotopic evidence for methane-based chemosynthesis in the Upper Floridan aquifer food web. Oecologia 150: 89-96.

Pedersen K., 2001 - Exploration of deep intraterrestrial microbial life: current perspectives. FEMS Microbiology Letters, 185: 9-16.
Pederson K. \& Ekendahl S., 1992 - Incorporation of $\mathrm{CO}_{2}$ and introduced organic compounds by bacterial populations in groundwater from the deep crystalline bedrock of the Stripa mine. Journal of General Microbiology, 138: 369-376.

Phelps T. J., Murphy F. M., Pfiffner S. M. \& White D. C., 1994 - Comparison between geochemical and biological estimates of subsurface microbial activities. Microbial Ecology, 28: 335-349.

Phelps T. J., Raione E. G., White D. C. \& Fliermans C. B., 1989 - Microbial activities in deep subsurface environments. Geomicrobiology Journal, 7: 79-91.

Pimm S. L., 1988 - Energy flow and trophic structure. In: Pomeroy L. \& Alberts J. (Eds.). Concepts of Ecosystem Ecology: Springer-Verlag, New York: 384p.

Popa R., 1997 - Fluxal energetic in ecosistemele acvatice subterrane din carstul dobrogean "Zone Pestera Movile". Ph.D. dissertation: Universitatea Bucuresti, Romania.

Por F. D., 2007 - Ophel: a groundwater biome based on chemoautotrophic resources. The global significance of the Ayalon cave finds, Israel. Hydrobiologia, 592: 1-10.

Porter M. L., 1999 - Ecosystem Energetics of Sulfidic Karst. M.S. thesis: Cincinnati, University of Cincinnati, $52 \mathrm{p}$.

Porter M. L., Russell S., Engel A. S. \& Stern L. A., 2002 Population studies of the endemic snail Physa spelunca (Gatropoda:Physidae) from Lower Kane Cave, Wyoming. Journal of Cave and Karst Studies, 64: 181.

Rohwerder T., Sand W. \& Lascu C., 2003 - Preliminary evidence for a sulphur cycle in Movile Cave, Romania. Acta Biotechnologica, 23: 101-107.

Sarbu S. M., Galdenzi S., Menichetti M. \& Gentile G., 2000 - Geology and biology of Grotte di Frasassi (Frasassi Caves) in Central Italy, an ecological multidisciplinary study of a hypogenic underground karst system. In: Wilkens H., Culver D., Humphreys S. (Eds.). Ecosystems of the World: Subterranean Ecosystems. Volume 30: Oxford, Elsevier Science: 361-381.

Sarbu S. M., Kane T. C. \& Kinkle B. K., 1996 - A chemoautotrophically based cave ecosystem. Science, 272: 1953-1955.

Sassen R., Roberts H. H., Aharon P., Larkin J., Chinn E. W. \& Carney R., 1993 - Chemosynthetic bacterial mats at cold hydrocarbon seeps, Gulf of Mexico continental slope. Organic Geochemistry, 20: 77-89.

Schauder R., Eikmanns B., Thauer R. K., Widdel F. \& Fuchs G., 1986 - Acetate oxidation to $\mathrm{CO}_{2}$ in anaerobic bacteria via a novel pathway not involving reactions of the citric acid cycle. Archives of Microbiology, 145: 162-172.

Schlesinger W. H., 1991 -Biogeochemistry: an analysis of global change. 2nd ed. Academic Press, San Diego CA, $302 \mathrm{p}$.

Schloss P. D. \& Handelsman J., 2005 - Introducing DOTUR, a computer program for defining operational taxonomic units and estimating species richness. Applied and Environmental Microbiology, 71: 15011506.

Simon K. S. \& Benfield E. F., 2002 - Ammonium retention and whole stream metabolism in cave streams. Hydrobiologia, 482: 31-39. 
Simon K. S., Gibert J., Petitot P. \& Laurent R., 2001 - Spatial and temporal patterns of bacterial density and metabolic activity in a karst aquifer. Archiv für Hydrobiologie, 151: 67-82.

Simon K. S., Pipan T. \& Culver D. C., 2007 - A conceptual model of the flow and distribution of organic carbon in caves. Journal of Cave and Karst Studies, 69: 279-284.

Singleton D. R., Furlong M. A., Rathbun S. L. \& Whitman W. B., 2001 - Quantitative comparisons of $16 \mathrm{~S}$ rDNA sequence libraries from environmental samples. Applied and Environmental Microbiology, 67: 4373-4376.

Smith V. H., 2007 - Microbial diversity-productivity relationships in aquatic ecosystems. FEMS Microbiology Ecology, 62: 181-186.

Stackebrandt E. \& Goebel B. M., 1994 - Taxonomic note: a place for DNA-DNA reassociation and $16 S$ rRNA sequence analysis in the present species definition in bacteriology. International Journal of Systematic Bacteriology, 44: 846-849.

Stevens T., 1997 - Lithoautotrophy in the subsurface. FEMS Microbiology Reviews, 20: 327-337.

Stevens T. O. \& McKinley J. P., 1995 - Lithoautotrophic microbial ecosystems in deep basalt aquifers. Science, 270: 450-454.

Swofford D. L., 2002 - PAUP*: Phylogenetic analysis using parsimony (* and other methods). V4.0b10.

Talavera G. \& Castresana J., 2007 - Improvement of phylogenies after removing divergent and ambiguously aligned blocks from protein sequence alignments. Systematic Biology, 56: 564-577.

Torsvik V., Ovreas L. \& Thingstad T. F., 2002 - Prokaryotic diversity: magnitude, dynamics, and controlling factors. Science, 296: 1064-1066.
Touminen L., 1995 - Comparison of leucine uptake methods and a thymidine incorporation method for measuring bacterial activity in sediment. Journal of Microbiological Methods, 24: 125-134.

Vlasceanu L., 1999 - Thriving in the dark: The microbiology of two chemoautotrophically-based groundwater ecosystems. Ph.D. Dissertation: Cincinnati, University of Cincinnati, $171 \mathrm{p}$.

Vlasceanu L., Popa R. \& Kinkle B., 1997 - Characterization of Thiobacillus thioparus LV43 and its distribution in a chemoautotrophically based groundwater ecosystem. Applied and Environmental Microbiology, 63: 31233127.

Vlasceanu L., Sarbu S. M., Engel A. S. \& Kinkle B. K., 2000 - Acidic cave-wall biofilms located in the Frasassi Gorge, Italy. Geomicrobiology Journal, 17: 125-139.

Waide R. B., Willig M. R., Steiner C. F., Mittelbach G., Gough L., Dodson S. I., Juday G. P. \& Parmenter R., 1999 - The relationship between productivity and species richness. Annual Review of Ecology and Systematics, 30: 257-300.

Wallace W., Knowles S. E. \& Nicholas D. J. D., 1970 - Intermediary metabolism of carbon compounds by nitrifying bacteria. Archives of Microbiology, 70: 2642.

Weber H., Kulbe K. D., Chmiel H. \& Trösch W., 1984 Microbial acetate conversion to methane: kinetics, yields and pathways in a two-step digestion process. Applied Microbiology and Biotechnology, 19: 224-228.

Wetzel R. G. \& Likens G. E., 1991 - Limnological Analyses, 2nd edition. Springer-Verlag New York, Inc., 449 p.

Whitman W.B., Coleman D.C., \& Wiebe W.J., 1998 Prokaryotes: The unseen majority. Proceedings of the National Academy of Science, U.S.A., 95: 6578-6583. 